\title{
SLS/BIALL Academic Law Library Survey 2013/2014
}

\section{David Gee}

Deputy Librarian

Institute of Advanced Legal Studies, School of Advanced Study, University of London

By-line This is the latest report analysing the results of the Society of Legal Scholars and BIALL Survey. It has been written by David Gee, Deputy Librarian at the Institute of Advanced Legal Studies, School of Advanced Study, University of London

\section{Summary of key findings}

- The response rate was $81.98 \%$; very good, and near the record of $85.4 \%$ (section 3);

- There was a marked increase again in new universities enrolling PhD and MPhil students (section 5);

- $22 \%$ of respondents failed to meet the SLS Statement of Standards 3.1 on space and physical facilities, through not housing all relevant collections in one place (section 6);

- The ratio of students to seats continued to worsen to its least favourable since statistics were first collected in the 1990s, with a median of 6.42 students to every seat in study areas by the law collection and a mean of 9.07 students per seat. Some respondents noted the difficulty of accurately identifying such seating where the law collection is just one of many collections or activity areas on a particular floor of the library building (section 7);

- On the other hand, the ratio of students to PC workstations located adjacent to the law collections and in the law school has improved, although some respondents noted difficulties when trying to identify accurately the number of PC workstations earmarked specifically for the use of law students (section 8);

- WiFi access was almost universally available within libraries in general, but less frequently available in the law collection itself (section 8);

- $24 \%$ of respondents reported an increase in the number of visits to the law library; $64 \%$ said numbers were constant and $12 \%$ reported a fall (section 9 );

- The results for term-time weekday opening indicate that there has been a significant increase in the number of libraries open for longer and a marked increase in the number of libraries opening for more than 100 hours per week. However, the median and average vacation opening hours decreased on 2012 (section 10);

- 26 libraries (9 old universities and 17 new universities) stated that they provided 24 hour access throughout the term to their paper-based collections. Overall this is a marked increase on the 12 libraries which provided 24/7 access in 2012 (section 10);

- Staffed issue services were available for a much longer time period, on average, than previously, whilst $96 \%$ of libraries provided self-issue (section 10);

- There was a slight decrease in the average number of hours during term-time when a reader enquiry service for law was provided by professionally qualified staff (section $10)$;

- $65 \%$ of libraries serving distance learning students provided three basic services: a link to the catalogue, a link to full-text databases and a link to full-text materials scanned into the VLE (section 11); 
- The three most popular law databases in terms of number of subscriptions continued to be Westlaw UK, Lexis®Library and HeinOnline. But there was still fluidity in the range of subscriptions held, for $17 \%$ of respondents were considering cancelling a subscription to an electronic source before the end of July 2015 whilst $17 \%$ were considering a new subscription before the same date (section 12);

- JSTOR was still the most widely used general database in law libraries (section 13);

- As a result of subscribing to law e-journal databases, $40 \%$ of those with access had cancelled a print subscription to a law journal (section 14);

- Just less than half of respondents (48\%) said they had cancelled subscriptions to the print version of law material during the current year, where the same resource was available electronically (section 14);

- Law journals and law reports were most frequently cut. Respondents said that the cuts were made on the basis of the availability of an electronic alternative and a desire to reappraise the worth of titles to the current aims of law teaching and research in the institution (section 14);

- The three most popular e-book publishers in terms of number of subscriptions were Dawsonera, My-i-library and EBSCO Host (section 14);

- Mean expenditure increased by $2 \%$ across all respondents on the level in 2013 . Old universities reported a $4.8 \%$ increase in mean expenditure on 2013 , whilst new universities reported a $0.51 \%$ increase in mean expenditure on 2013 (section 15.1);

- Mean expenditure on law materials per student in old universities was £231 (up $5.78 \%$ on 2013) whereas in new universities it was £238 (a 3.11\% decrease on 2013). The pattern in this area is therefore of a narrowing gap between sectors (section 15.1).

- The proportion of total law material expenditure on monographs increased to $22 \%$, serials were down to its lowest ever at $45 \%$ and databases remained steady at $33 \%$ (section 15);

- Separate results on overall expenditure on law library materials in institutions not providing vocational or professional award courses are provided (section 15.7);

- The highest proportion of income to fund the acquisition of law materials continued to come from general library funds (section 16);

- $67 \%$ of all law schools made no contribution at all to funding the acquisition of law materials, a higher percentage than in past years. However, of those law schools that did contribute, they appeared to do so more generously with the mean amount contributed by law schools increasing by $12 \%$ on last year (section 16);

- A higher percentage of responding libraries did not have any library staff which spent $50 \%$ or more of their working time on the care and servicing of the law collection. Several explained that their activities were being diluted into library-wide responsibilities or the law collection was being serviced from a team of staff with wider subject duties (section 17);

- Overall average staffing numbers slightly increased in old universities to 3.46 FTE, but slightly decreased in new universities to 2.37 FTE (section 17);

- $86 \%$ of respondents had at least one member of law library staff who had a LIS qualification, although for 20 institutions this was less than one full-time member of staff (section 17.4); 
- As found in previous surveys, library staff with law qualifications were much more common in old universities (section 17.4);

- $84 \%$ of respondents were aware of the revised SLS Statement of Standards (2009 version) and as many as $60 \%$ had used the Statement in discussions on funding and administration (section 18);

- In 2006 a majority of respondents considered that only a marginal move to electronic provision of legal materials would occur in the next five years. In 2014 a majority of $54 \%$ of respondents considered a significant move towards electronic provision likely in the next five years (section 19.1);

- $56 \%$ of respondents felt that over the next five years the proportion spent in their library on the purchase of law monographs as compared with law serials would remain constant (section 19.2);

- $67 \%$ of respondents considered that over the next five years the proportion spent on purchasing legal materials relating to the law of Great Britain and European Union as compared with foreign and international law would remain constant. Interestingly, the next largest group of law libraries (20\%) thought the proportion spent would move marginally in favour of purchasing more legal materials relating to foreign and international law (section 19.3).

\section{Introduction}

The following report outlines the activities and funding of academic law libraries in the UK and Ireland in the academic year 2013/2014. The figures have been taken from the results of a survey questionnaire undertaken by Academic Services staff at the Institute of Advanced Legal Studies on behalf of the Society of Legal Scholars (SLS).

This survey has been run on an annual basis since 1996 and reported in The Law Librarian and latterly in Legal Information Management. It is sponsored either by the British and Irish Association of Law Librarians (BIALL) or by the Society of Legal Scholars (SLS).

I shall attempt to draw comparisons with previous surveys where helpful. In particular "2013" refers to the 2012/2013 data (Gee, 2014), "2012" refers to the 2011/2012 data (Gee, 2013) and "2011" refers to the $2010 / 2011$ data (Gee, 2012). All the previous surveys referred to are referenced at the end of the report.

\section{$2 \quad$ Methodology}

The survey methodology followed the improvements made last year, conveniently making an electronic editable PDF form version of the survey questionnaire available to be completed. In February 2015 an email containing both a link to the survey questionnaire on the IALS website and an attached editable PDF form was dispatched to 111 institutions in the UK and Ireland. Respondents could therefore complete the electronic questionnaire at one sitting, save it under the name of their institution and email it back to us. Alternatively they could print out the questionnaire to work on over a period of time and then complete the electronic version, save it and email it back to us. We were also still happy to receive completed paper versions of the survey questionnaire by post if this was the method preferred by individual respondents.

As in the past research centres with no students or only small numbers of postgraduates where the main university law library was invited to respond to the survey, were excluded. For similar reasons, the Oxbridge college libraries were excluded but, as usual, responses from the Bodleian and Squire law libraries were invited. 
This year's survey is funded by the Society of Legal Scholars (SLS). A copy of the questionnaire is available on the IALS website at:

http://ials.sas.ac.uk/library/SLS BIALL survey.htm

\section{$3 \quad$ Response rates}

This year 91 forms were returned representing a response rate of $81.98 \%$, a slight decrease on last year's $83.78 \%$, but still close to the record of $85.4 \%$, set in $2003 / 2004$. I am grateful to all those law librarians who took the time to respond. A complete list of the academic law libraries that returned a completed $2013 / 2014$ survey questionnaire is contained in the Appendix. I am not usually made aware of the reasons for non-returns, but this year I was told that several libraries were recruiting new law librarians and this explained why they did not return a completed questionnaire. Another key reason for the delayed returns was that law librarians are finding it more difficult to extract relevant data (particularly financial data) from the central university. On our part we try to be very flexible and have permitted some respondents to take up to eight weeks to send in a promised reply.

Another response rate of over $80 \%$ is very welcome and should permit the presentation of a reasonably accurate picture of academic law libraries in the UK and Ireland.

To help detect patterns in law library provision, the data has been analysed, as in previous years, by type of institution:

- "old" universities incorporated before 1992

- "new" universities incorporated in or after 1992

- institutes of higher education and other types of institution

Forty-five old universities responded (43 last year), as did 43 new universities (47 last year) and 3 other institutions ( 3 last year). The response profile has therefore changed slightly, with two more results for old universities and four fewer results from new universities. This may affect comparisons with past results.

\section{$4 \quad$ Definitions}

In many of the following sections, the survey responses are analysed using range, mean and median.

- The range indicates the smallest and the greatest value of the responses and helps us understand the diversity of responses.

- The mean has been calculated by adding up all the responses and dividing by the number of responses to get an "average". The mean can be distorted by one or two responses which are very large or very small.

- The median is the mid point and is calculated through ordering the responses by size from the smallest to the greatest and finding the middle response. There will be an equal number of responses below the median and above the median and so it provides a benchmark of what a "typical" university is doing.

All percentages from this point onwards have been rounded to the nearest whole number.

\section{$5 \quad$ Student numbers}

A representation of the number of law students served by the libraries helps in understanding the framework in which provision is made and can assist librarians in comparing their provision with institutions of similar sizes.

Respondents were asked to indicate the total number of taught course students (bodies, not FTEs) in the Law School enrolled on exempting undergraduate law degrees or professional or academic postgraduate courses in law. Eighty seven out of the total of 91 respondents gave 
figures for student numbers, ranging from 50 to 10,083 (47 to 7,000 in 2013). The median number of law students was 700 (676 in 2013). The mean number however was 955 (876 in 2013), a significant increase again.

Respondents in old universities reported student numbers between 50 and 1,939 (47 to 1,835 last year), with a mean of 888 (844 last year) and a median of 900 (860 last year). In new universities, the range was 81 to 10,083 (71 to 7,000 last year), with a mean of 1,095 (957 last year) and a median of 530 (572 last year). Among the 3 other institutions, the range was 85 to 225 (90 to 220 in 2013). The mean was 143 (142 in 2013) and the median was 120 (117 in 2013). Some movements are evident in the number of students attending responding institutions in 2013/2014 as compared with the previous year. In particular the average number of students in both old and new universities have increased.

Ninety or $99 \%$ of respondents (92 or $99 \%$ in 2013) offered an exempting undergraduate law degree. Twenty eight or $31 \%$ of respondents (31 or 33\% in 2013) hosted the Legal Practice Course (LPC) or Bar Professional Training Course or Diploma in Professional Legal Practice (Scotland) or Professional Practice Course (Ireland) or Degree of Barrister-at-law (Ireland). This represents $22 \%$ of old university respondents, $42 \%$ of new universities and $0 \%$ of other institutions.

Twenty two or $24 \%$ (22 or $24 \%$ in 2013 ) of respondents provided courses leading to other law professional awards, such as the CPE or Chartered Institute of Legal Executives qualification. Sixteen percent of old universities, 30\% of new universities and $67 \%$ of other institutions ran such courses. The final category was for other taught courses, such as LLM, which led to a postgraduate award in law. Eighty three or $91 \%$ ( 86 or $93 \%$ in 2013) of institutions ran these postgraduate courses, including $98 \%$ of old and $91 \%$ of new universities and $0 \%$ other institutions. The movements in the percentages of respondents offering particular courses this year are relatively small and are probably mainly due to changes in the survey profile.

Respondents also indicated whether the law school enrolled students onto research courses, such as those leading to $\mathrm{PhD}$ and MPhil. Overall 75 or $82 \%$ (74 or $80 \%$ in 2013) of institutions indicated that they did. Ninety eight percent of old universities, $72 \%$ of new universities and $0 \%$ of other institutions had such students. Research students were not included in the count of law students detailed above. Whilst the percentage for old universities has fallen back slightly from the $100 \%$ in 2013 , the trend is up markedly for the new universities $(66 \%$ in 2013).

This year we again asked about the number of students enrolled on distance learning courses for law. The question was last posed in 2012. Twenty six institutions or $29 \%$ (2012: 28 or $30 \%$; 2010: 24 or $27 \%$ ) offered this mode of study, including 3 with unspecified numbers. Student numbers ranged from 7 to 1,325 (2012: 2 to $624 ; 2010: 6$ to 1,500). The median number of students was 58 (2012: 48; 2010: 77) and the mean 184 (2012: 119; 2010: 48). Ten or $22 \%$ of old universities (2012: $29 \%$ ) had students enrolled on distance learning courses; the number of students ranged from 7 to 97 , with a median of 27 students. Thirteen or $30 \%$ of new universities (2012: $34 \%$ ) had distance learning students, with numbers ranging from 7 to 1,325 , and a median of 109. Although, in general, relatively small numbers of students are enrolled on distance courses, libraries provide special support arrangements which are investigated in section 11, below.

\section{$6 \quad$ Location of the law library}

Respondents were asked to indicate, from a list, which most closely matched the circumstances in their institution. 


\section{Location of the law library}

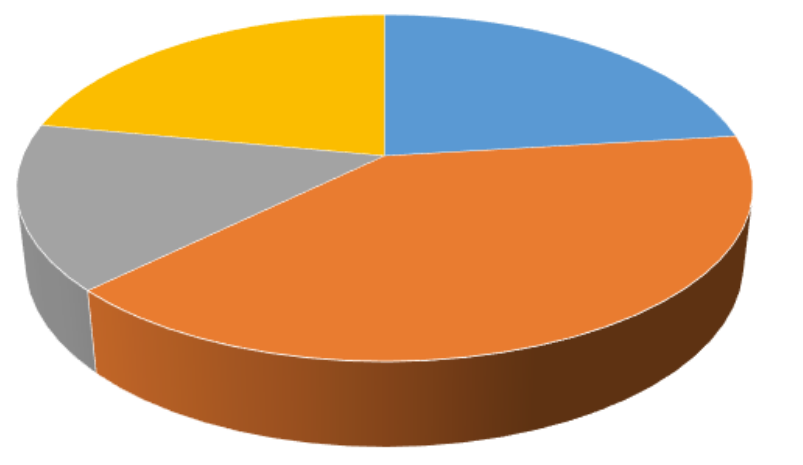

- Single law library

— Single identifiable unit

- Several law collections

- Dispersed law collection

Graph 1: Location of the law library

As the above pie chart demonstrates, across all respondents:

- $23 \%$ had a single law library in a location separated from other subject collections (29\% in 2013). Of these, there were 16 (2013: 17) old universities, 4 (2013: 9) new and 1 (2013: 1) other institution.

- $\quad 40 \%$ had a law collection not so separated but shelved so as to form a single identifiable unit (38\% in 2013). These included 16 (2013: 16) old universities, 18 (2013: 17) new and 2 (2013: 2) other institutions.

- $15 \%$ had several law collections each in a different location (22\% in 2013). These included 4 (2013: 6) old, 9 (2013: 15) new universities and 1 (2013: 0) other institution.

- $\quad 22 \%$ had a law collection dispersed wholly or partly among other subject collections (11\% in 2013). Of these, 9 (2013: 4) were old universities, 11 (2013: 6) were new universities and 0 (2013: 0 ) other institutions.

Thirty six percent (2013: $40 \%$ ) of old universities responding had a single and separate law library, while $10 \%$ (2013: $19 \%$ ) of new universities and $25 \%$ (2013: $33 \%$ ) of other institutions had a single and separate law library.

Thirty six percent (2013: $37 \%$ ) of old universities described their law collection as being shelved so as to form a single identifiable unit but not separate from other collections. Forty three percent $(2013: 36 \%)$ of new universities described their law collection in a similar way, and $50 \%$ (2013: $66 \%)$ of other responding institutions.

Eight percent (2013: $9 \%$ ) of old universities had several law collections, each in a different location, but $21 \%(2013: 13 \%)$ of new universities and 1 institution $(25 \%)$ reported several collections (2013: 0, 0\%).

As in past surveys, the main reason for more than one law collection was the establishment of a separate library targeted at vocational course students, such as those on the LPC or BPT, in addition to a main law collection. Other respondents mentioned other reasons for separate locations, for example, all the journals were shelved separately from the law collection. 
The comments to the SLS Statement of Standards 3.1 (Society of Legal Scholars, 2009) on space and physical facilities require "the housing of all relevant collections ... as a unified whole in one place ...". This year the figures suggest that this criterion was not met by at least the $22 \%$ of institutions reporting dispersed collections.

Twenty percent of old universities, $26 \%$ of new universities and $0 \%$ of other institutions had law collections wholly or partly dispersed among other subject collections. Last year the figure was $11 \%$ overall: in detail, in $2013,9 \%$ of old, $13 \%$ of new and $0 \%$ of other institutions had dispersed collections.

Although the percentage trend of dispersed collections has increased markedly on 2013, one must remember that the general response profile for different types of institution has altered a little between last year's and this year's surveys, so the actual institutions responding are different and are probably partly the reason for the upward changes noted.

\section{$7 \quad$ Provision of seating}

Respondents were asked to indicate the number of seats in study areas by the law collection/s, excluding workstation places. This question has been asked in alternate years so the data for 2014 can be compared with that for 2012 and 2010.

Seventy nine institutions provided figures. The figures ranged from 6 to 1,350 with a mean of 205 (2012: 207; 2010: 204) and a median of 100 (2012: 123; 2010: 120). The results must be viewed with some caution. As has been noted in section 6 above, there is a significant number of institutions where the law collection is not separate from other subjects, and respondents have taken different views on how to count the amount of seating which was 'by the law collection' as required by the survey question.

A more useful measure is the ratio of students to seats. Seventy six of the 79 responding institutions were able to provide data for both variables. The ratio ranged from 0.43 to 61.22 students per seat, with a median of $6.42(2012: 5.74 ; 2010: 5.7)$ and a mean of 9.07 students per seat (2012: 8.42; 2010: 8.20). The data was analysed according to the type of institution. The 41 old universities had a ratio of between 0.43 and 24 (2012: 0.33 and 36.1; 2010: 0.6 and 15.9$)$ with a median of $6.09(2012: 5.39 ; 2010: 4.83)$. Thirty one new universities had a ratio of between 1 and 61.22 (2012: 0.26 and $80.89 ; 2010: 0.60$ and 56.60 ) with a median of 6.63 (2012: $6.64 ; 2010: 7.70)$. The 3 other institutions had a ratio of between 0.89 and 14.39 (2012: 1.04 and 11.60; 2010: 1.70 and 13.40), with a median of 10.55 (2012: 6.32; 2010: 4.69).

Fifty four percent (2012: 58\%; 2010: $60 \%$ ) of old universities were at or below the overall median ratio of $6.42 \%$, as compared with $48 \%$ (2012: $42 \%$; 2010 : $38 \%$ ) of new universities and $33 \%$ (2012: $50 \%$; 2010: $60 \%)$ of other institutions.

A further analysis highlights the differences between the various categories of respondent: $15 \%$ of old universities were in the quartile of respondents with the least favourable student to seat ratios, as compared with $32 \%$ of new universities and $50 \%$ of other institutions (2012: $13 \% ; 39 \%, 50 \% ; 2010: 12 \%, 38 \%, 40 \%$ ). The percentage of old universities appearing in the quartile with the least favourable student seat ratios, is $2 \%$ higher than in 2012, while the percentage of new universities with the least favourable student seat ratios is $7 \%$ lower than in 2012.

The median ratio of students to seats in a selection of past surveys has been 1994: $3.50: 1$, 2004: 5.30:1, 2006: 5.60:1, 2008: 5.40:1, 2010: 5.70:1 and 2012: 5.74:1. This year's ratio of $6.42: 1$ is the least favourable ever reported. Some caution should be expressed in using the student : seat ratio, for many librarians noted the difficulty of identifying the number of 'seats by the law collection', where the trend in design is towards seating areas provided according to different study environments (silent, quiet, group activity) rather than made available to serve a particular subject. 
The ratio may be compared with the former University Grants Committee ratio for law libraries of 2:1. This ratio received indirect endorsement in the Follett Report of 1993. Further, the comments to SLS Standard 3.2 states that 'a ratio of students per seat exceeding 5:1 should be regarded as high and in need of early reduction, or of compensation through extended opening hours'. The survey results indicate that study space is under continuing pressure from student numbers in all sectors but, as discussed in section 10 below, there continues to be a considerable increase in the opening hours of responding libraries. Finally one could speculate that this seemingly worsening position regarding the median ratio of students to seats without workstations may not be as unfavourable as it first appears as it may just mean that the overall number of seats have remained about the same, but that more seats are gaining a PC workstation. This speculation could be correct as we shall see from section 8 where the median ratio of students to workstations has decreased again to the most favourable ever reported.

\section{$8 \quad$ Workstations}

The survey asked respondents to indicate the number of PC or Mac workstations which can access electronic law materials, and are available for law student use:

- adjacent to, or in the same building as, the law collection

- in the building where the law school is housed.

In response to the first part of the question, a number of respondents noted that although the workstations counted as 'in the same building as the law collections' they were shared with non-law students. It was difficult to determine accurately the numbers available for law student use. Further, some respondents not only included fixed workstations but noted the number of laptops available for student use. The questions on workstation provision were devised originally in the mid-1990s, when the SLS was concerned about the level of investment in IT hardware. But since then developments in library facilities and computer technology (and the availability of laptops and tablets for loan in many libraries) have made accurate tracking of the relative ease of law student access to IT less reliable.

Eight-five respondents $(93 \%)$ provided figures for the numbers of workstations near the law collections. The numbers ranged from 3 to $1,353-51 \%$ (the median) had at least 215 (2012: 203; 2010: 130) and the mean was 275 (2012: 239; 2010: 218). The very positive trend of providing additional workstations to complement traditional study places seems to have accelerated.

Seventy eight respondents (86\%) provided figures for the number of workstations in the law school. Of these, 22 law schools did not have any workstations for student use (2012: 28 2010: 20). For those who did, the range was from 0 to 585 (2012: 0 to 600), with a mean of 62 (2012: 58; 2010: 104) and a median of 31 (2012: 21; 2010: 50). Comparing 2014 with 2012, the range of numbers and means remain reasonably constant. The median in 2014 has increased on 2012; this may be due to changes in the responses profile.

The ratio of law students to workstations gives a more effective picture of the levels of provision. The figures for workstations adjacent to the law collections and in the law school were combined for this measure. 81 (2012: 87) institutions were able to provide data for both parts of the ratio.

The ratio ranged from 0.21 to 176 students per workstation (2012: 0.14 to $50 ; 2010: 0.15$ to 33.33), with a median of 2.13 (2012: 2.34; 2010: 3.80) and a mean of 6.99 (2012: 5.52; 2010: 6.17). Thirty-five institutions had a ratio of law students to workstations of less than 2 students per PC (2012: 39; 2010: 28). When interpreting these figures the comments at the beginning of this section should be noted: the difficulty of identifying accurately the numbers of PCs "in the same building as the law collections", where they were shared with non-law students.

As in the past surveys on this topic, the results for the average law student to workstation ratio were dissimilar in the old and new university sectors. 
In the 41 old universities, the mean ratio was 6.52 and the median was 2.59 (2012: 7.40 and 3.19; 2010: 7.74 and 5.16). For the 37 new universities, the mean was 7.86 and the median was 1.48 (2012: 3.52 and 1.15; 2010: 4.70 and 1.87). The figures for the 3 other institutions were a mean of 3.24 and a median of 2.00 (2012: 1.65 and 1.65; 2010: 3.61 and 3.00).

The overall median ratio of students to workstations in a selection of past surveys has been 2010: $3.80: 1$ and 2012: 2.34:1. This year's ratio of 2.13:1 is the most favourable ever reported. Although some caution should be expressed in using the student to workstation ratio, for many librarians noted the difficulty of identifying the number of 'workstations by the law collection'.

For the third time a question was included on the provision of WiFi access to law databases in different locations across the institution. All 91 respondents answered. Sixty seven (74\%) provided access adjacent to the law collection (2012: 76\%); 91 (100\%) provided access within the university or college library in part or whole (2012: $99 \%)$; $87(96 \%)$ in the law school building (2012: 88\%); $82(90 \%)$ in student halls (2012: 83\%) and $86(95 \%)$ in other parts of the institution to which students have access (2012: 89\%). It is notable again that WiFi access is almost universal within the library in general, but less frequently available in the law collection in particular.

\section{$9 \quad$ Library use}

This year we continued to monitor trends in the number of visits to the law library, last measured in 2012. The aim was to determine whether increased access to law databases from outside the university or college campus had affected the number of visits to the library. The question asked respondents to compare the number of visits to the law collections in 2013 with 2014. The question recognised that a level of judgement would be needed but asked respondents to note the basis for their comparison. Eighty-four institutions responded. Twenty institutions or $24 \%$ (2012: $41 \%$; 2010: 33\%) saw an increase in visits, in 54 or $64 \%$ (2012: $47 \%$; 2010: $56 \%$ ) the number of visits remained constant, and in 10 or $12 \%$ (2012: $12 \% ; 2010: 11 \%)$ the number of visits decreased. Therefore the majority of institutions reported that the number of visits remained constant.

Thirty nine $(46 \%)$ respondents mentioned more than one basis for comparison. Personal observation was mentioned 61 times (2012: 66), exit gate logs 32 times (2012: 30), SCONUL statistics 16 (2012: 21), issue desk statistics 4 (2012: 4), occupancy counts not attributed to SCONUL headcount 4 (2012: 4), one to one student appointment statistics 2 (2012: 0), demand for material 2 (2012: 0), online usage statistics 2 (2012: 0), shelving / feedback statistics 1 (2012: 2) and enquiry desk statistics 1 (2012: 1). The continued heavy reliance on personal observation as the basis for comparison might suggest the results are subjective rather than objective.

\section{Opening hours and services}

Opening hours were last surveyed in 2012. For the 91 responding libraries $(2012: 91 ; 2010$ : 88) the median number of term-time weekly opening hours was 103.5 (2012: 96; 2010: 84). The mean for weekly term-time hours was 116.13 (2012: 105.75; 2010: 92.39). Hours ranged from 52.5 to 168 (2012: 52 to $168 ; 2010$ : 50 to 168). Twenty six libraries (29\% of all respondents, 9 old universities and 17 new universities) stated that they provided 24 hour access throughout the term to their paper-based collections. Overall this is a marked increase on the 12 libraries in 2012. Forty-nine responding libraries were open for more than 100 hours per week (2012: 43; 2010: 25); they were 22 old, 27 new and no other institutions (2012: 21 old, 22 new and 0 other; 2010: 12 old, 12 new and 1 other).

Eighty seven respondents gave details of opening hours in vacation. The median for weekly opening times was 54 hours (2012: 62 hours; 2010: 54) and the mean was 57 hours (2012: 70.1; 2010: 60.8). 
The results for term-time weekday opening indicate that there has been a significant increase in the number of libraries open for longer, a significant increase in the number providing 24 hour access to print collections, and a marked increase in the number of libraries opening for more than 100 hours per week. However, the median and average vacation opening hours decreased on 2012.

All 91 respondents gave details of term-time weekend opening. Two did not open on Saturdays $(2012: 1 ; 2010: 2)$. The number of institutions opening on Sundays increased slightly. In 2014, 94.5\% of institutions opened as compared with $93 \%$ of institutions in 2012 and $89 \%$ in 2010 . In previous years the incidence of term-time Sunday opening used to vary between types of institution. However in 2014 there is no gap between old and new universities: $98 \%$ of old universities, $98 \%$ of new universities, $25 \%$ of other institutions (2012: 94\% of old universities, $98 \%$ of new universities; $2010: 89 \%$ of old universities, $95 \%$ of new universities, and $40 \%$ of other institutions). The results for term-time weekend opening in $2013 / 2014$ indicate continued extensions in opening hours.

Information was sought on the time at which the law library closed in a standard term-time week, Monday to Thursday. This information was first sought in the 2002 survey. Eight-eight respondents provided this information. 29 libraries, comprising 12 old universities and 17 new universities, stated they provided 24 hours access during these days (2012: 20, comprising 7 old universities and 13 new universities; 2010: 13, comprising 5 old universities and 8 new universities). Of the remaining 59 libraries, 11 or $12.5 \%$ (2012: 13 or $15 \%$; $2010: 19$ or $22 \%$ ) closed at $10 \mathrm{pm}$ and 4 or $4.5 \%$ (2012: 7 or $8 \% ; 2010: 14$ or $16 \%$ ) at $9 \mathrm{pm}$. 24 libraries or $27 \%$ closed at midnight. The earliest closing time was still 7pm (2012: 7pm; 2010: 7pm) and the latest closing time (aside from libraries which opened 24/7) was still 2.30am (2012: 2.30am; 2010: 2.00am). The median time was 10.30pm (2012: 10.30pm; 2010: 10.00pm).

Not all facilities are necessarily available throughout opening hours. To help provide an indication of key opening hours respondents were asked to indicate the number of hours during a term-time week when a staffed book loan service was available for law items. Eighty five institutions responded. For these 85 respondents the mean was 62.4 hours (2012: 59.9 hours; 2010: 68.5 hours). The median was 69 hours (2012: 69 hours; 2010: 70 hours). The range was 0 hours to 96.5 hours (2012: 0 hours to 138 hours; 2010: 0 hours to 137.3 hours). Nine institutions ( 2 old and 7 new) reported that there was no staffed issue service and they were entirely reliant on self-service for issuing materials. This is less than in 2012 (14 institutions, 5 old and 9 new).

This year, the survey results for the availability of a staffed book loan service show an increase in the average number of hours for which this service was available to patrons and a decrease in the number of institutions with no staffed issue service.

As in 2012, 2010 and 2008 we asked whether respondents provide a self-issue system for use with items from the law collection. For 2014, 96\% (2012: 93\%; 2010: 90\%) said they did provide self-issue facilities.

88 respondents $(97 \%)$ indicated the number of hours during term-time weeks that a reader enquiry service for law was provided by professionally qualified staff. Hours when professional staff could only offer a service of referral onto a law specialist were to be excluded. Five respondents did not provide a reader enquiry service for law (2012: 1; 2010: 7). For the remainder, the mean number of hours for which an enquiry service was available was 34.8 hours (2012: 37.4 hours; 2010: 36.9 hours) and the median was 37 hours (2012: 37 hours; 2010: 37 hours). The range was 0 to 79 hours (2012: 0 to 82 hours; 2010: 2 to 79 hours). $57 \%$ of respondents provided an enquiry service for between 35 and 40 hours per week (2012: 58\%; 2010: 62\%).

Therefore in 2014 there was a slight decrease in the average number of hours a reader enquiry service for law was provided and a slightly reduced concentration of availability within the range of 35 to 40 hours a week.

As in 2012 we asked about membership of reciprocal borrowing schemes. 
All 91 respondents provided details. Eighty respondents (88\%) were members of SCONUL Access (2012: 97\%).

Eleven (12\%) were members of SCONUL RX (2012: 32\%).

Thirty three (36\%) were members of regional schemes (2012: 44\%).

Seven (8\%) were members of other schemes (2012: 10\%) providing specialised reciprocal borrowing or access arrangements with other institutions. The Invicta Borrowing Scheme and the RUN scheme were mentioned.

\section{Distance learning}

At the request of the Society of Legal Scholars (SLS) we again asked questions this year about special support provided by the law library for distance learning courses. As has been noted in section 5, above, only 26 or $29 \%$ of respondents (2012: 28 or $30 \%$ ) offered this type of course. Five of these institutions ( 3 old universities and 2 new universities) had made arrangements for their distance learning students studying law to have access to a physical (not electronic) law library other than at the institution where they were registered and outside the national reciprocal borrowing schemes mentioned in section 10 above. 4 institutions (1 old university and 3 new universities) provided no additional support other than reciprocal borrowing arrangements.

Twenty three institutions provided additional support to distance learners other than that already described (2012: 21 institutions).

Seventeen or $65 \%$ (2012: 15 or $54 \%$ ) provided postal loans, 17 or $65 \%$ (2012: 13 or $46 \%$ ) a phone/e-mail/fax legal research enquiry service, 13 or $50 \%$ (2012: 15 or $54 \%)$ provided postal delivery of photocopying (subject to copyright) and 3 or $12 \%$ (2012: 5) undertook database searches by library staff on behalf of the distance learning students. Also mentioned, by 7 respondents (2012: 8) was the provision of study packs of readings, 2 respondents mentioned scanning copies via email.

Twenty respondents or $77 \%$ (2012: 17 or $81 \%$ ) offered a package including more than one of the services noted.

Some further questions probed the nature of the additional services a little deeper. All 26 or $100 \%$ of institutions (2012: $100 \%$ ) offering law by distance learning provided access for learners outside the campus to databases and learning materials. All 26 or $100 \%$ (2012: $100 \%$ ) also used a virtual learning environment (VLE) for the delivery of law distance learning courses. All 26 of these institutions provided details of how to access law library materials (by which was meant the law and commentary on it) through the VLE. Respondents were asked to include as many means of access as applied.

Twenty three or $89 \%$ (2012: 28 or $100 \%$ ) provided a link to the library catalogue, 24 or $92 \%$ (2012: 26 or $93 \%$ ) provided links to full text online subscription databases, 19 or $73 \%$ (2012: 24 or $86 \%$ ) scanned full text material into the VLE. One respondent a piece mentioned: direct access to specific cases and journal articles on subscription databases; a library portal for access to a range of guides / self-help / bibliographies; digitised content on online reading lists; using the "Talis Aspire reading list system" to access digitised readings; and links to free internet resources.

Twenty five or $96 \%$ (2012: 28 or $100 \%$ ) of institutions provided more than one means of access, with 17 or $65 \%$ (2012: 22 or $79 \%$ ) providing all three suggested means of access on the questionnaire: link to library catalogue, link to full text databases and full text of materials scanned into the VLE. 
Contrary to the rest of the questionnaire, respondents were asked to indicate their legal database subscriptions at the present time, rather than in the year 2013/2014. The results below therefore show the position in February 2015.

As in recent years, all respondents gave details of subscription databases used in connection with the teaching and research work of the law school. The ten most frequently mentioned law databases are displayed in the graph below.

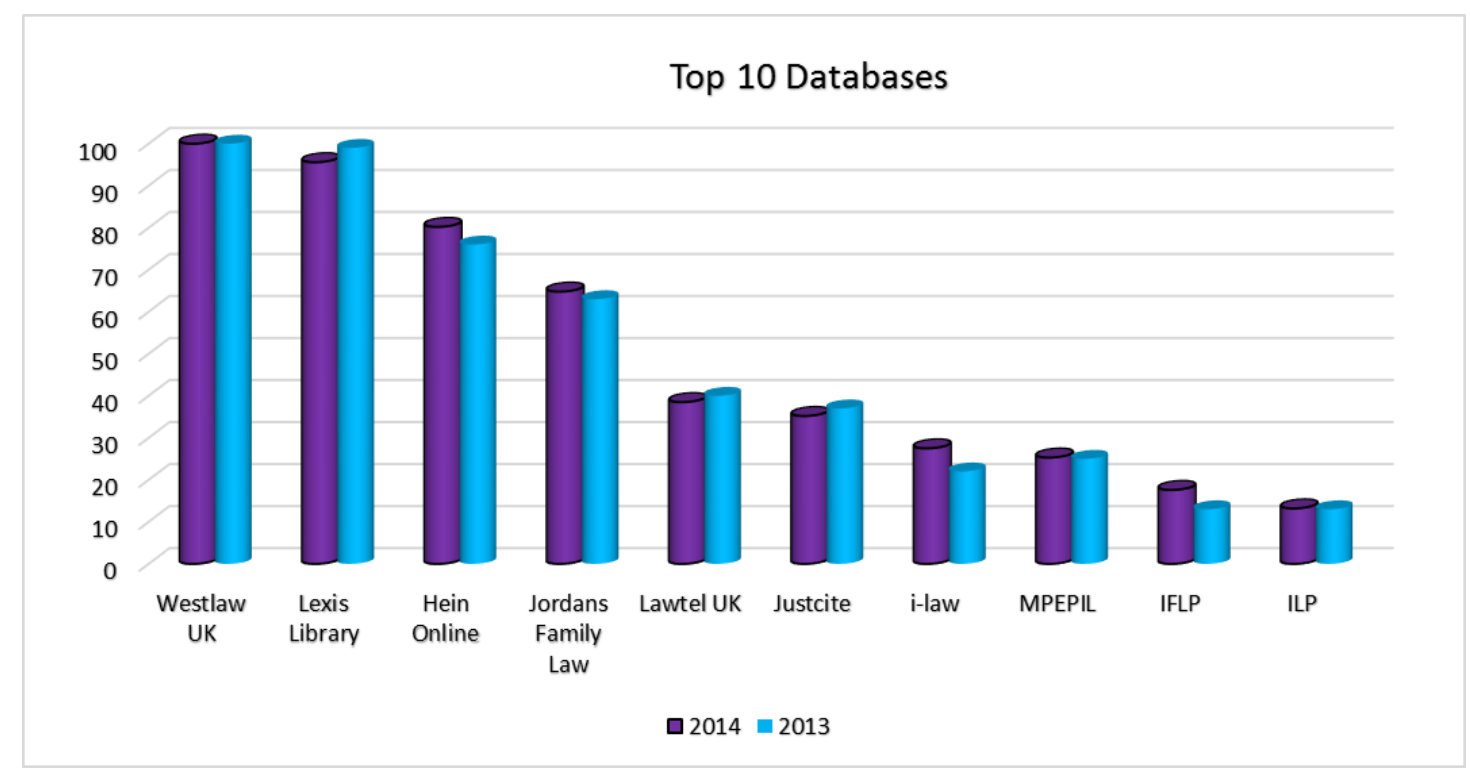

Graph 2: Top 10 legal databases

The law databases' academic market is still fluid but much less than several years ago and generally similar to last year. On a positive note, $17 \%$ of respondents $(18 \%$ last year and $11 \%$ the year before) were planning new subscriptions before the end of July 2015. However on the negative side, $17 \%$ (10\% last year and $7 \%$ the year before) noted planned or recent cancellations before the financial year end.

Like last year, a small number of law databases continue to dominate the market. According to the snapshot survey results using exactly the same survey questions format as in the previous year, in February 2015 Westlaw UK was taken by 91 respondents (100\%) and Lexis $\AA$ Library was taken by 87 of respondents $(96 \%)$. Last year Westlaw UK was also taken by $100 \%$ of respondents and Lexis ${ }^{\circledR}$ Library was taken by $99 \%$. HeinOnline, kept the third position it first gained in 2007 with an increased percentage, being taken by 73 or $80 \%$ of respondents (last year: 75\%). Jordan's Family Law Online remained in fourth place with $65 \%$ (63\% last year).

Of the other databases mentioned by respondents, Lawtel UK remained in fifth place with 35 or $39 \%$ of respondents taking the database (37 or $40 \%$ last year) and Justcite remained in sixth place with $35 \%$ of respondents (37\% last year). i-law moved up one place to seventh place with $28 \%$ of respondents and the Max Planck Encyclopedia of Public International Law moved down one place to eighth place with the same percentage of $25 \%$ as last year. IFLP maintained the same ninth place as last year with an increased percentage of $18 \%$ of respondents. ILP dropped one place to tenth place but had the same percentage rating of $13 \%$ of respondents as last year.

Looking at the returns for Westlaw in more detail, no respondents were planning to cancel subscriptions and two respondents reported plans to extend their coverage of subscriptions in the year to July 2015 by subscribing to "Westlaw eBooks" and "loose-leaf books on Westlaw". 
Seventy four respondents or $81 \%$ subscribed to Westlaw International (67\% last year). Twenty one respondents (7 last year) subscribed to Westlaw IE (Irish Law). Two were based in the Irish Republic, one from Northern Ireland and the rest from the UK mainland.

Respondents were asked to indicate the subscriptions they took to particular parts of the Lexis ${ }^{\circledR}$ Library product. One respondent reported planning to cancel their subscription to Encyclopaedia of Forms and Precedents and one reported that they were planning to subscribe to "more Lexis practice areas".

The Journals module and the UK cases module were the most popular products, both taken by $92 \%$ of respondents. The UK legislation module was the next most popular, taken by $91 \%$ of respondents. Halsbury's Laws was taken by $80 \%$ of respondents and UK newspapers on Lexis by $71 \%$, whilst the International Materials module was taken by $66 \%$ of respondents. The Encyclopaedia of Forms and Precedents in electronic format was taken by $51 \% .11$ respondents or $12 \%$ took Lexis PSL.

30 respondents ticked "other Lexis®Library products" in the survey questionnaire. However most did not specify specific products so it is difficult this year to give a safe popularity percentage split between the other Lexis ${ }^{\circledR}$ Library products, other than to say that the following products were mentioned by many respondents: Employment Law, Accountancy lite, Atkins Court Forms, Company and Commercial, Immigration and Human Rights, IP, and Tax.

Two respondents stated that they subscribed to LexisNexis ${ }^{\circledR} J u r i s$ Classeur and one respondent took Lexis Middle East Law as standalone products.

HeinOnline retained its third position with an increased percentage, being taken by 73 or $80 \%$ of respondents (last year: $75 \%$ ). One respondents reported that they were planning to cancel their Hein "Supreme Court Library" and "Legal Classics" subscriptions because of the increased cost of subscription, whilst one respondent reported plans to subscribe to "HeinOnLine Journals" and one respondent reported plans to subscribe to "HeinOnLine".

Jordan's Family Law Online remained in fourth place with 59 respondents or $65 \%$ (59 or $63 \%$ last year). One respondent reported plans to subscribe to Jordan's before July 2015.

Lawtel UK took fifth place with $39 \%$ of respondents taking the database ( $40 \%$ last year). Two respondents reported plans to cancel their Lawtel UK subscription.

Justcite took sixth place with $35 \%$ of respondents (37\% last year). Two respondents were planning to cancel their subscription to Justcite before $31^{\text {st }}$ July 2015 , whilst one respondent was hoping to subscribe.

Other than the databases already discussed in detail, the following databases were mentioned by $10 \%$ or more respondents:

$\begin{array}{lrrr} & \begin{array}{r}2015 \\ \text { Institutions }\end{array} & \begin{array}{r}2015 \\ \%\end{array} & 2014 \\ \text { i-Law } & & & \\ \text { Max Planck Encyclopedia of PIL } & 25 & 28 \% & 22 \% \\ \text { Index to Foreign Legal Periodicals } & 23 & 25 \% & 25 \% \\ \text { Index to Legal Periodicals } & 16 & 18 \% & 13 \% \\ & 12 & 13 \% & 13 \%\end{array}$

Databases cited by 3 or more respondents included Kluwer Arbitration and PLC Online (9 respondents each), Oxford Reports on International Law and Oxford Scholarship Online (6 
respondents each), OGEL - Oil, Gas and Energy Law (4 respondents), Beck, Casetrack and WorldTradeLaw.net (3 respondents each).

In total 23 respondents (or 25\%) subscribed to Justis products other than Justcite. Although not all respondents gave full details of their Justis subscriptions the following limited information was given: 7 respondents subscribed to JUSTIS, 6 respondents subscribed to UK legislation, 4 to both International Law Reports and Irish Reports, and 2 to the Parliament module. One respondent each subscribed to BLISS, Caribbean Law Reports, Mental Health Reports and Transcripts.

Databases of European legal information continued to be casualties in the changing academic legal database market. Eurolaw was subscribed to by 2 respondents or $2 \%(1 \%$ last year). Only 1 respondent noted a subscription to another full-text EU database.

The median number of legal database subscriptions taken in responding libraries in February 2015 was 7 (February 2014: 6). The numbers of legal databases offered by institutions ranged from 2 to 49 ( 2 to 46 last year).

\section{Other databases}

In addition to law databases, law schools use a range of more general information databases such as the newspapers which are of relevance to students in a wide range of disciplines. Eighty three respondents (91\%) noted other subscription databases which contribute significantly to the teaching and research work of their law school. This shows a marked percentage increase from the $84 \%$ recorded last year.

JSTOR was again the most widely used general database with 69 or $76 \%$ of respondents (2013: 60 or $65 \%$ ). House of Commons Parliamentary Papers (HCPP) was mentioned by 59 or $65 \%$ of respondents (2013: 50 or $54 \%$ ) and gained second place. Third was EBSCO Business Source with 50 or $55 \%$ (2013: 49 or 53\%) and fourth was ISI Web of Science with 43 or $47 \%$ (2013: 45 or $48 \%$ ). Fifth was ASSIA with 26 or $29 \%(2013: 21$ or $23 \%)$ and sixth was EBSCO academic with 25 or $28 \%$ (2013: 21 or $23 \%$ ). Next was Criminal Justice Abstracts at 20 or $22 \%$ (2013: 19 or $20 \%$ ). The following databases were used by fewer than $10 \%$ of respondents: SCOPUS (5 or $5.5 \%$ of respondents); Public Information Online and Science Direct and Times Digital Archive (all used by 3 or $3 \%$ of respondents); Sage and Xpert (both used by 2 or $2 \%$ of respondents). A further 31 non-law subscription databases were mentioned only once.

By February 2014,60 or $66 \%$ of respondents used a web-based combined newspaper database to access the full range of newspapers (2013: 54 or $58 \%$ ), although not every respondent specified a particular database. Taking into account all those respondents who did specify particular databases, the top three suppliers were again Nexis UK used by 24 respondents (2013: 32), Proquest with 14 respondents (2013: 15) and Factiva with 6 respondents (2013: 9). Gale NewsVault was again taken by 4 respondents (2013: 4), and Infotrack and Newsbank were again both taken by 3 respondents (2013: Infotrack and Newsbank both had 3). The following databases were mentioned once: Academic Onefile; Access World News; allafrica.com; Daily Mail Historical Archive; FBIS Daily; Irish Times Archive; Times Digital; UK Press Online. The results for this year indicate the continued popularity of Nexis UK, Proquest and Factiva. Otherwise the results show only slight changes in the subscriber newspaper databases used to contribute significantly to teaching and research in the law school.

\section{E-journals and e-books}

Every other year since 2004, we have asked questions about electronic journals and books, a sector of the publishing market which has developed rapidly in the last few years. We repeated the same questions as used in 2012 , to try to gauge the impact electronic materials are having on print subscriptions. 
Seventy six, or $87 \%$ of respondents $(2012: 85,92 \%)$ said they subscribed to an electronic journal database which includes law titles, excluding Lexis $®$ Library, Westlaw UK, HeinOnline, e-journal gateways (e.g. SwetsWise) and special deals (e.g. NESLI). The pattern across different types of institution showed a reduced take-up amongst old and new universities on previous years. Forty two were old universities (2012: 47), 31 were new universities (2012: $37)$ and 3 (2012: 1) were other types of institution.

However, as a result of subscribing to law e-journal databases 30 , or $40 \%$, of those with access had cancelled a print subscription to a law journal (2012: 43 or 51\%). Seventeen old universities (2012: 24), 12 new universities (2012: 19) and 1 other institutions (2012: 0) had replaced a law journal print subscription with electronic access.

An increased number of institutions: 37 or $48 \%$ of respondents (2012: 44 or $48 \%$ ) said they had cancelled subscriptions to the print version of law material during the current year where the same resource was available electronically. They were 20 old universities, 15 new and 2 other types of institution.

As in 2006, 2008, 2010 and 2012 we sought more information about the impact electronic subscriptions were having on print subscriptions. Were institutions starting to cut specific print subs when the same material was available electronically? Which types of print publication were being cut? Were there differences in the cuts made by the different types of institution?

Twenty seven institutions (2012: 36) provided details of the titles of print materials they had cancelled where the same material was available electronically. They comprised 14 old institutions, 11 new and 2 other. A further 4 respondents (2012: 5) said there were too many titles to list or they did not have the information. Of those who sent lists 8 mentioned more than 10 publications (some considerably more) and 5 had lists of between 5 and 10 titles.

Excluding instances where respondents said they were cancelling duplicate subscriptions to leave only a single subscription, a total of 159 print titles were cancelled (2012: 177). That number excludes four vague answers (2012: 5), one respondent stating "no more than 5 journals"; one stating "some loose-leafs"; one stating "various titles dependent on format available from publisher"; and one stating there were too many print title cancellations in favour of the electronic version to list. All this adds up to a substantial number of cancellations in one year, although perhaps fewer overall than was recorded in previous years leading one to speculate that the number of print cancellations in favour of an electronic alternative may have reached a plateau for the time being.

In 2014 the cancellations axe fell almost entirely on print law journals and law reports. Of the 159 specifically mentioned cancelled print titles, 72 were law journals and 55 titles were law reports (in 2012118 law journal titles and 24 law report titles were cancelled). Looking only at journals, old universities mentioned 47 titles which had been cancelled (43 in 2012), whilst new universities mentioned 25 cancellations (75 in 2010). Fewer print law report titles were cancelled: 10 by old universities (2012: 11), 39 by new universities (2012: 13) and 6 by other institutions (2012: 0).

The titles cancelled included both core and specialised titles. For example core titles such as Business Law Review and CMLR were cancelled. The jurisdictional spread of both the law journal and law report titles cancelled was less wide-ranging than in previous years, covering mainly the UK and the EU (although public international law material, Australian, USA (Federal and State) and New Zealand law materials were also cancelled). The decision to cancel appeared to be motivated not just by the availability of an electronic equivalent, but also a desire to reappraise the worth of titles to the current aims of law teaching and research in the institution.

In 2012 two print subscriptions to Halsbury's Statutes were reported cancelled and replaced with online versions, whilst in 2014 there were six cancellations in favour of the online version. Three cancellations to Halsbury's Statutory Instrument's print subscriptions in favour of the online version were also recorded in 2014. 
The remaining cancelled print titles were mainly loose-leaf works and digests.

In summary, this snapshot of cancellations indicates that the priority for cancellation appears to remain with law journals and law reports including though not exclusively, those available electronically.

We asked two questions to gain an impression of which parts of the law collection had sustained cuts and why. Of the 55 respondents who reported cuts, 25 or $46 \%$ reported the cuts falling more heavily on domestic law materials, 20 or $36 \%$ falling equally on UK and foreign, comparative and international (FCIL) materials; and 10 or $18 \%$ more heavily on FCIL materials.

Fifty one of the 55 respondents gave reasons for where the cuts fell, some citing different factors. The most frequently cited ( 9 times) was that the cuts had to fall on UK materials because there were either, very few or no FCIL materials held. Second most frequent $(8$ times) was the availability of materials in electronic format, resulting in the cancellation of print subscriptions. A number of respondents commented that jurisdiction was immaterial; format was the driver, along with student preference for electronic versions.

As in 2006, 2008, 2010 and 2012 we asked about subscriptions to e-book publishers. Ninety respondents (2012: 91$)$ listed the e-book publishers to which they subscribed for law titles. They were 45 old universities and 42 new universities and 3 other types of institution.

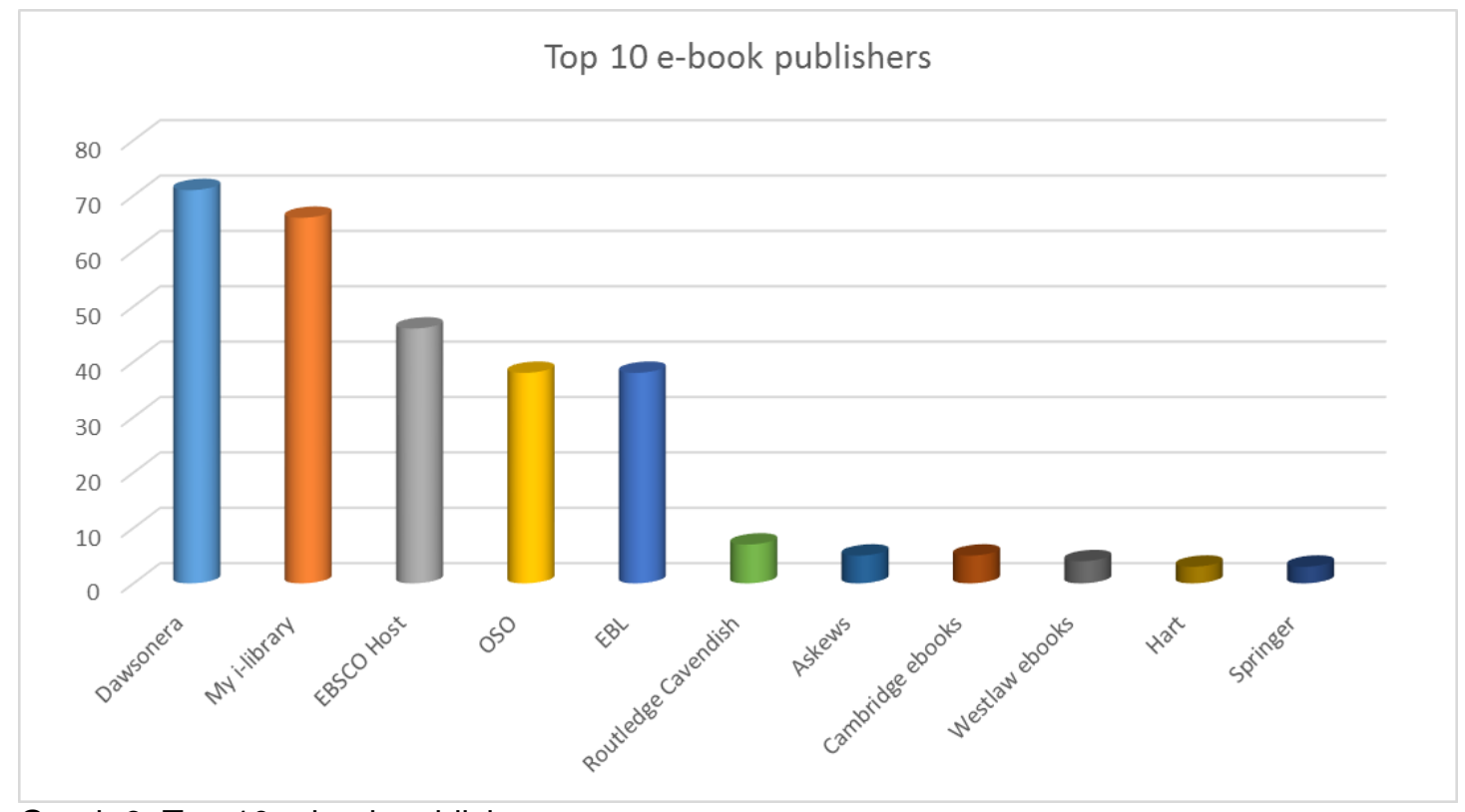

Graph 3: Top 10 e-book publishers

As the graph above shows, 71 subscribed to Dawsonera (2012: 76), 66 subscribed to My-ilibrary (2012: 65), 46 to EBSCO Host (2012: 2), 38 to Oxford Scholarship Online (2012: 40), 38 to EBL (2012: 9), 7 to Routledge Cavendish (2012: 2), 5 each to Askews and Cambridge e-books, 4 to Westlaw e-books and 3 each to Hart and Springer. Finally, 2 each to Brill and Palgrave, and a further 6 niche suppliers were taken by just one library each.

\section{Expenditure}

Seventy nine of the 91 libraries (or $87 \%$ of respondents) were able to provide total expenditure figures for $2013 / 2014$. Those respondents who did not respond either could not disaggregate law expenditure from other subjects or were not prepared to provide the information. 


\subsection{Total expenditure on law materials}

Total expenditure on the acquisitions of law materials ranged from $£ 7,706$ to $£ 1,251,890$ (2013: $£ 14,664$ to $£ 1,705,506)$. Mean expenditure was $£ 186,787$ (2013: $£ 182,715$ ), a $2 \%$ increase on 2013. This increase in expenditure on 2013 (following on from a 6\% increase and a $7 \%$ increase in previous years) is very welcome, although to sound a note of caution the increase may be partly a reflection of the changing pool of survey respondents.

It is helpful in understanding these changes to compare the expenditure in the different types of institution.

Old universities: 38 out of a possible 45 responses (2013: 42 out of 43)

Range from $£ 36,984$ to $£ 726,998$; median $£ 167,111$ (decreased by $0.23 \%$ on 2013 ); mean $£ 202,688$ (increased by $4.8 \%$ on 2013 ). $75 \%$ of old universities spent at least $£ 115,260$ (up $2.1 \%$ on last year). $25 \%$ spent more than $£ 281,149$ (up $21.8 \%$ on last year).

New universities: 38 out of a possible 43 responses (2013: 44 out of 47) Range $£ 28,471$ to $£ 1,251,890$; median $£ 113,198$ (up $1.8 \%$ on last year); mean $£ 183,546$ (up $0.51 \%$ on last year). $75 \%$ of new universities spent at least $£ 69,004$ (down $9.1 \%$ on last year) and $25 \%$ spent more than $£ 195,000$ (up by $10.3 \%$ on last year).

Other institutions: 3 responses (2013: 3)

This sample is too small to be meaningful or anonymous.

These very welcome results seem to indicate that the financial climate is continuing to improve on 2013 across the sectors. For both old and new universities the expenditure on law materials results are generally positive across the key indicators.

For each law student in a typical university (looking at the median) £197 was spent on law materials. This is a tiny $0.46 \%$ decrease on the figure for 2013 .

However, the rate of increase has not been evenly distributed across the higher education sector. In an old university, median spend per student was £202 (2013: £201) but for a student in a new university the median was $£ 182$ (2013: £193), a widening gap between old and new universities of 9.9\% (2013: $4 \%$ ). In other types of institution the median spend per student was £135 (2013: £248). As graph 5 illustrates, the gap between old and new universities fluctuates over time but widened in 2013/2014 due to a slight increase in median expenditure in old universities and a much larger decrease in the median for new universities. Per capita expenditure at other types of institution decreased substantially. However this marked statistical change is due to the very tiny sample of just 3 respondents. 


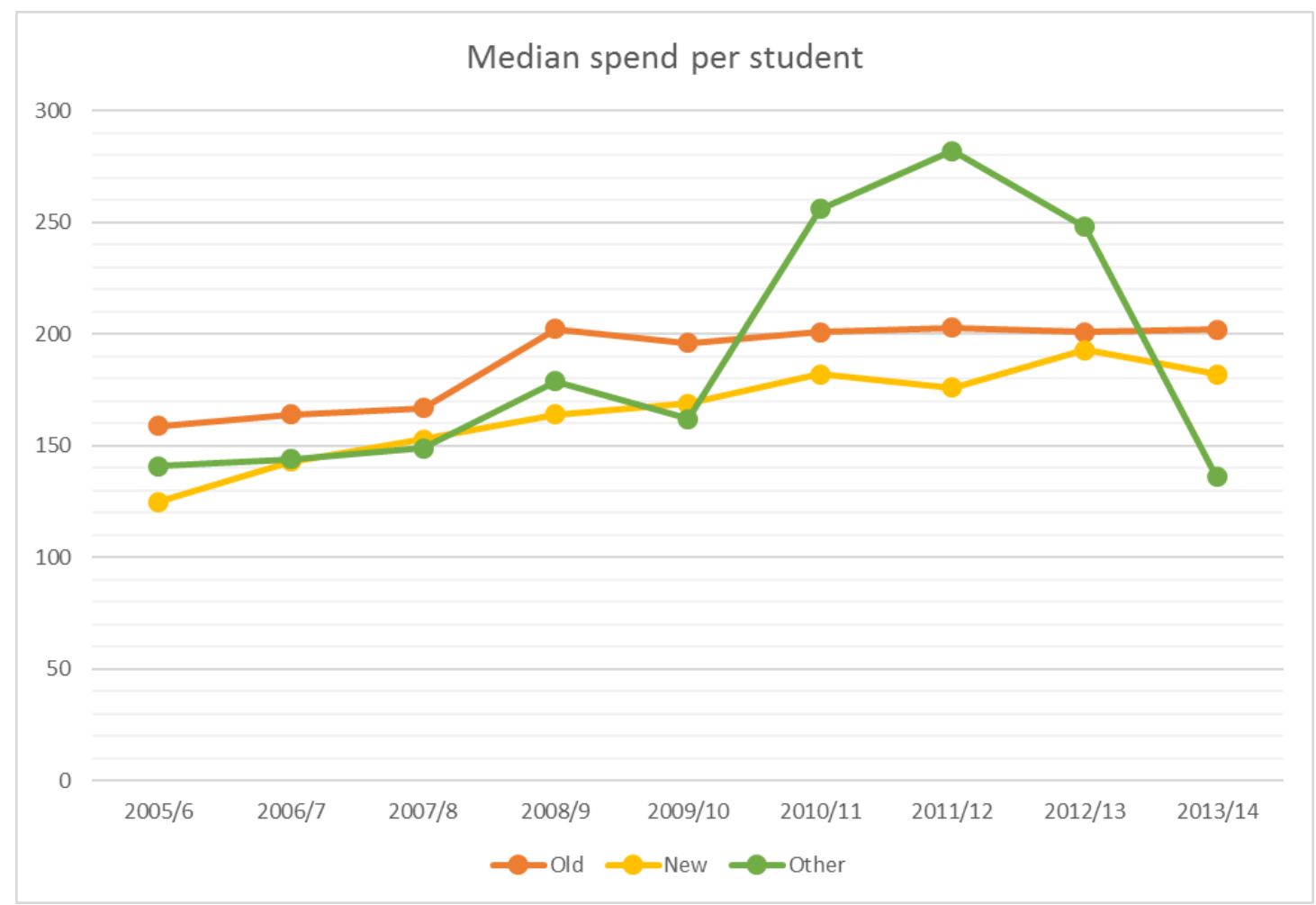

Graph 5: Library materials expenditure per student

Taking the mean, rather than the median, the pattern is different with a continuing narrowing of the gap between sectors. Mean spend per student at new universities continues to overtake the mean spend per student at old universities, but the gap is narrowing. Mean law materials expenditure per student in old universities was £231, up $5.78 \%$ from 2013 whereas in new universities it was $£ 238$, down $3.11 \%$ on 2013 . In other types of institution the mean spend per student was $£ 156$ (2013: $£ 220$ ), indicating a steep decrease, but these results have been calculated over just 3 respondents.

\subsection{Monograph expenditure}

Seventy six respondents provided details of spending on books, nine fewer than last year. Some respondents had difficulty providing a discrete and accurate figure for law expenditure alone owing to the way the university or college budget is divided amongst subject areas.

Expenditure on monographs ranged from $£ 1,992$ to $£ 276,150$ (2013: $£ 1,848$ to $£ 289,817$ ), with a mean of $£ 38,698$, an increase of $7 \%$ on 2013 and a median of $£ 23,580$ a decrease of $4.3 \%$ on last year.

In 2014, on average, monograph acquisitions accounted for $22 \%$ of total law material expenditure (2013: $21 ; 2012: 21 \% ; 2011: 21 \%)$. The proportion of total expenditure spent on books ranged from $4 \%$ to $71 \%$ with a median of $22 \%$ (2013: $4 \%$ to $57 \%$ with a median of 18 ; 2012: $3 \%$ to $53 \%$; with a median of $20 \%$; $2011: 4 \%$ to $56 \%$, with a median of $19 \%$ ).

Analysed by type of institution the figures for monograph expenditure were:

Old universities: 36 respondents (2013: 40)

Range $£ 5,946$ to $£ 207,117$; median $£ 28,880$, a decrease of $3.85 \%$ on last year; mean $£ 45,724$ a substantial increase of $19.63 \%$ on 2013 . Mean of $23 \%$ of total law material expenditure (2013: 20\%; 2012: 21\%; 2011: 20\%).

New universities: 37 respondents (2013: 43) 
Range $£ 3,491$ to $£ 276,150$; median $£ 19,625$, a decrease of $6 \%$ on last year; mean $£ 34,460$, a decrease of $0.75 \%$ on last year. Mean of $22 \%$ of total law material expenditure (2013: $21 \%$; 2012: $22 \%$; 2011: 22\%).

Other institutions: 3 institutions (2013: 2 )

The range, median and mean figures are not very useful because of the tiny sample. Mean of $37 \%$ of total law material expenditure (2013: $27 \%$; 2012: $22 \%$ 2011: $16 \%$ ).

The mean figure for new universities showed a small decrease of $0.75 \%$ in expenditure on monographs, whilst the mean figure for old universities showed a substantial increase of $19.63 \%$. The percentage of total law expenditure devoted to monographs has increased slightly for both old and new universities. Please note that these figures may be partly a reflection of the changing pool of survey respondents.

\subsection{Serials expenditure}

Seventy four of the 91 respondents who gave any financial figures were able to provide a figure for their spending on serials, eleven fewer than last year. The questionnaire defined serials as law journals, statutes, law reports and loose-leaf updates.

As a mean, serials accounted for $45 \%$ of total law materials expenditure (2013: $46 \%$; 2012 : $49 \%$; $2011: 50 \%)$. The proportion of expenditure given to serials ranged from $9 \%$ to $80 \%$ (2013: $6 \%$ to $78 \%$; 2012 : $4 \%$ to $81 \%$; $2011: 10 \%$ to $88 \%$ ) with a median of $45 \%$ (2013: $50 \%$; 2012: $50 \%$; 2011: 51\%). Overall, serials expenditure ranged from $£ 2,885$ to $£ 449,671$ (2013: $£ 2,274$ to $£ 543,500)$, with a median of $£ 61,665(2013$ : $£ 64,249)$ and a mean of $£ 89,484$ (2013: $£ 89,302)$, the median down by $4.2 \%$ (2013: down by $6 \%$ ) and the mean slightly up by $0.2 \%$ (2013: down by $6 \%)$.

Analysed by type of institution the figures were:

Old universities: 36 responses (2013: 40)

Range $£ 9,803$ to $£ 449,671$; median $£ 90,173$, up $3.4 \%$ on last year; mean $£ 105,199$, down by $2.8 \%$ on last year. Mean of $50 \%$ of total law material expenditure (2013: $51 \%$; $2012: 53 \%$; 2011: 53\%).

New universities: 35 responses (2013: 43)

Range $£ 3,684$ to $£ 345,187$; median $£ 52,000$, up $8.8 \%$ on last year; mean $£ 79,672$, up $3.2 \%$ on last year. Mean of 41\% total law material expenditure (2013: 43\%; 2012: 45\%; 2011: $46 \%)$.

Other institutions: 3 responses (2013: 2)

The range, median and mean figures are not very useful because of the tiny sample. Mean of $44 \%$ of total law material expenditure (2013: 47\%; 2012: 39\%; 2011: 46\%).

The percentage of total law expenditure devoted to serials has continued to fall for both old and new universities. Please note that these figures may be partly a reflection of the changing pool of survey respondents.

\subsection{Database expenditure}

Databases continued to account for $33 \%$ of total law materials expenditure in the mean, ranging from $7 \%$ to $78 \%$ with a median of $30 \%$ (2013: mean of $33 \%$, median of $30 \% ; 2012$ : mean of $30 \%$, median of $26 \%$; 2011 : mean of $29 \%$, median of $28 \%$ ). Of the 71 responses (2013: 82), expenditure ranged from $£ 2,899$ to $£ 709,740$ (2013: $£ 6,633$ to $£ 1,072,922)$ with a median of $£ 37,136$ (2013: $£ 34,320$ ), a rise of $7.6 \%$ on last year, and a mean of $£ 61,678$ (2013: $£ 60,689)$, a small increase of $1.59 \%$ on last year.

Analysed by type of institution the figures were: 
Old universities: 33 respondents (2013: 38)

Range $£ 18,076$ to $£ 167,915$; median $£ 43,079$, an increase of $6.16 \%$ on last year; mean $\{53,486$, a slight decrease of $1 \%$ on last year. Median $27 \%$ and mean $29 \%$ of total law material expenditure (2013: 25\% and 29\%; 2012: $22 \%$ and 26\%; $2011: 23 \%$ and $28 \%$ ).

New universities: 36 respondents (2013: 42)

Range $£ 12,286$ to $£ 709,740$; median $£ 34,215$, up $4.6 \%$ on 2013 ; mean $£ 72,253$ up $4.5 \%$ on last year. Median $34 \%$ and mean $38 \%$ of total law material expenditure (2013: $33 \%$ and $36 \%$; 2012: $30 \%$ and 33\%; 2011: $30 \%$ and 33\%).

Other institutions: 2 respondents (2013: 2)

The range, median and mean figures are not very useful because of the tiny sample. Median and mean both $27 \%$ of total law material expenditure (2013: $37 \%$ and $37 \% ; 2012: 39 \%$ and $39 \%$; 2011 : $18 \%$ and $29 \%$ ).

Median spending on databases in both old and universities has increased on last year. The median percentage of total law expenditure devoted to databases has continued to increase for both old and new universities. Please note that these figures may be partly a reflection of the changing pool of survey respondents.

\subsection{E-book expenditure}

Twenty five respondents provided details of spending on e-books (28 last year). It is important to point out that more respondents probably purchase e-books, but that they were not all able to provide discrete and accurate figures for this law expenditure alone owing to the way the university or college budget is divided amongst subject areas. As a consequence the following e-book expenditure figures should be treated with some caution, but they are of interest nevertheless.

Expenditure on e-books ranged from $£ 721$ to $£ 27,628$, with a mean of $£ 7,928$ and a median of $£ 5,545$.

Analysed by type of institution the figures for e-book expenditure were:

Old universities: 12 respondents (2013: 13)

Range $£ 1,621$ to $£ 20,000$; mean $£ 6,937$; median $£ 5,926$.

New universities: 13 respondents (2013: 14)

Range $£ 721$ to 227,628 ; mean $£ 8,842$; median £5,545.

Other institutions: 0 institution (2013: 1)

No data to calculate figures.

\subsection{Other expenditure on law materials}

Ten respondents noted "other" expenditure, nine fewer than last year. Expenditure ranged from $£ 12$ to $£ 45,000$ (2013: $£ 96$ to $£ 48,000)$, with a median of $£ 1,134(2013: £ 1,223)$ a $7.8 \%$ decrease, and a mean of $£ 5,346(2013$ : $£ 4,529)$ an increase of $15 \%$.

Only 3 respondents specified what the "other" expenditure was spent on: 2 stated inter-library loans, and 1 stated binding.

\subsection{Expenditure by institutions not providing vocational or professional award courses}


At the suggestion of one respondent we have carried out some analyses on expenditure by those institutions which offer only an exempting law degree or LLM courses, that is, do not offer vocational courses, such as the LPC, BPTC, Diploma in Legal Practice (Scotland) or Professional Practice Course (Ireland) or Degree of Barrister-at-law (Ireland) or courses leading to professional awards, such as the CPE and CILEx. These institutions believe that vocational courses require the purchase of expensive practitioner materials and so the results given earlier in section 15 are inflated and make comparison with their situation very difficult. So, we have re-run the analyses for total expenditure.

Total expenditure on the acquisition of law materials ranged from $£ 11,520$ to $£ 726,998$ (2013: $£ 21,433$ to $£ 706,500$ ). Mean expenditure was $£ 162,061$ (2013: $£ 155,876)$, a $3.8 \%$ increase on 2013. To sound a note of caution the results are probably partly a reflection of the changing pool of survey respondents.

It is helpful in understanding these changes to compare the expenditure in the different types of institution.

Old universities: 32 respondents, 27 provided financial data (2013: 31, 30 provided financial data)

Range £36,984 to £726,998 (2013: £36,506 to £706,500); median £202.377 (2013: $£ 187,332)$, a $7.4 \%$ increase on last year; mean $£ 223,847(2013$ : 203,611 ), a 9\% increase on last year.

New universities: 23 respondents, 20 providing financial data (2013: 20, 19 provided financial data)

Range $£ 28,471$ to $£ 195,000$ (2013: $£ 21,433$ to $£ 382,816$ ); median $£ 70,423$ (2013: $£ 72,000$ ), a decrease of $2.2 \%$ on 2013 ; mean $£ 86,176$ (2013: $£ 87,532$ ), a decrease of $1.6 \%$ on last year.

Other institutions: 1 respondent (2013: 1)

Comparing these results with those in paragraph 15.1 for all respondents, there are differences between the medians and means in old universities, but much more significant are the differences between the medians and means amongst new universities. The reason for the differences lay in the numbers of students at each institution - those new universities which do not offer vocational courses have generally smaller numbers of students than those new universities that do, hence a smaller expenditure on the acquisition of library materials. This distinction is less marked at old universities.

\section{Sources of income}

Seventy eight (2013: 88) respondents gave details of the source of the funds from which law material expenditure was met.

The greatest proportion of acquisitions was funded from general library funds, and all but 2 institutions responding received at least part of their income this way. Using the mean, $90 \%$ of old universities', $95 \%$ of new universities' and $100 \%$ of other institutions' income for law library materials was from general library funds $(88 \%, 93 \%$ and $100 \%$ last year). When the median is used the figures are $94 \%, 100 \%$ and $100 \%$ (2013: $95 \%, 100 \%$ and $100 \%)$. The increase in the mean percentage for old universities indicates an increase in focus on general library funds, and the slight increase in the mean percentage and the no change in the median percentage for new universities indicates a slight increase or at worse no change in focus on general library funds as the source on last year.

Law schools contributed to funding the acquisition of law materials in 30 institutions (2013: 34 ). As has been noted in previous survey reports, a considerable and growing number of law schools make no such contribution at all $(67 \%$ this year, $61 \%$ in $2013,58 \%$ in $2012,57 \%$ in 2011). This downward trend is reflected in the fact that, $44 \%$ (2013: $52 \%)$ of old university law schools, $23 \%$ (2013: $30 \%)$ of new university law schools and $0 \%(2013: 0 \%)$ of other institutions' schools contributed something. 
Of the law schools that contributed, the amount ranged from $£ 491$ to $£ 228,415$ (2013: $£ 1,000$ to $£ 85,330$ ). The median contribution was $£ 14,647$, a decrease of $17 \%$ on last year. The mean was $£ 28,008$, up $12 \%$ on last year.

For the libraries that received funds from the law school, these funds represented a mean of $18 \%$ of the total income for the purchase of law materials, with a median of $13 \%(16 \%$ and $11 \%$ last year). This year the mean percentage contributions by law schools based in old and new universities narrowed to $1 \%$ with old universities contributing a slightly higher mean percentage than new universities. Of the old university law schools who contributed anything, the mean contribution represented $19 \%$ of the funds for library materials $(2013: 14 \%)$, while new university law schools contributed less at 18\% (2013: 21\%). No 'other' institutions received funds from the law school (2013: 0\%).

In the old universities, median law school funding for law materials was $£ 14,950$, down $5.5 \%$ on last year. The mean was $£ 32,404$, up by $34 \%$ on last year. In new universities the comparative figures were a median of $£ 12,808$, down by $67 \%$ on last year and a mean of $£ 19,215$, down by $63 \%$ on 2013 .

In summary for law school contributions: well over half of all law schools make no contribution to funding the acquisition of law materials, a higher percentage than in past years. However there was an increase in the old University law schools' average contribution (at 19\% in 2014) to the total funds for library materials (up 5\% on last year), although there was a $3 \%$ fall in the new university law school's average contribution (at 18\%) to the total funds for library materials.

The actual average amount of money contributed by old university law schools increased markedly by $34 \%$ on last year, whilst the actual average amount of money contributed by new university law schools decreased markedly by $67 \%$ on last year.

Six institutions (2013: 6) reported receiving income from other university budgets for law materials. For these 5 old universities, 1 new universities and 0 other institutions, the amount of income from these sources ranged from $£ 7,457$ to $£ 119,664$ (2013: $£ 3,500$ to $£ 170,267$ ).

No respondents reported funding from user charges (2013: 1).

Finally, 2 institutions (2013: 3) reported receiving financial contributions towards law materials from outside bodies. The sums ranged from $£ 51,197$ to $£ 79,700$ (2013: $£ 12,000$ to $£ 157,000$ ), with a median income of $£ 65,448(2013: £ 100,000)$ and a mean income of $£ 65,448$ (2013: $£ 89,667)$. These were both old universities.

\subsection{Targeted funding from the law school}

Two further questions sought to explore whether law schools paid for specific materials or services.

The first question asked respondents to indicate whether specific types of materials were paid for by the law school. 29 respondents (32\%) replied in the positive (2013: 30, 32\%) with some respondents mentioning more than one type of material. By far the most frequently mentioned was payment of, or contributions towards, the cost of electronic databases such as Lexis Library, Westlaw or HeinOnline - 21 respondents (2013: 15). Seven respondents noted that the law school contributed towards the cost of law books, journals or reports (11 in 2013) ranging from research journals to specialist monographs to multiple copies of textbooks. Library materials for the Legal Practice Course or Bar Vocational Course were mentioned specifically by 3 respondents ( 5 in 2013).

In the second question in this section, respondents were asked to indicate whether the law school contributed to law library expenditure other than for the purchase of law materials. 
Only 4 respondents $(7$ in 2013) received this additional funding. Three indicated the total amount of the contribution, ranging from $£ 11,200$ to $£ 48,000$ (2013: $£ 7,600$ to $£ 48,000$ ).

Respondents reported receiving funding towards the cost of law librarian staff salaries.

\section{Staffing}

The responses to the questions on staffing provide a picture of the number and qualifications of library staff in academic law libraries. The definition of law library staff provided in the questionnaire was the same as for the previous surveys. To be included in the survey, library staff were to spend $50 \%$ or more of their working time on the care and servicing of the law collection.

Thirteen (or 14\%) of the 91 responding institutions had no staff which met this criterion (2013: 7 or $8 \%$ ). Of these, 9 (2013: 5) were old universities and 4 (2013: 2) were new universities. In most instances respondents mentioned that law was just one of a number of subjects for which a team of librarians was responsible, but no one spent the requisite $50 \%$ or more of their time on law alone, or that their responsibilities were diversifying into library-wide activities.

For the 78 respondents (2013: 84) with staff who met the criterion, the full-time equivalent (FTE) number of staff ranged from 0.20 to 23.25 (2013: 0.25 to 24.6 ) with a median of 1.0 (2012: 1.0$)$ and a mean of 2.86 (2013: 2.75). 38.5\% (2013: 34.5\%) had exactly one FTE member of law library staff.

As in previous surveys, old universities ranged most widely in the number of law library staff and $25 \%$ had four or more FTE (2013: $18.9 \%$ ), compared to only $10.3 \%$ of new universities (2013: 11.4\%).

The median for old universities' FTE law library staffing was 1.0 (2013: 1.0) with a mean of 3.46 (2013: 3.25). The median for new universities was 1.0 (2013: 1.0) and the mean was 2.37 (2013: 2.4). The three other institutions were varied in their staffing levels, from 1 to 4 FTE (2013: 1 to 4$)$.

The staffing figures therefore portray an improving picture for old universities, whereas the mean indictor for new universities suggest a slightly less positive situation on the previous year. The overall mean number of staff increased from 2.75 to $2.86 \mathrm{FTE}$, the mean number of staff for old universities increased from 3.25 to $3.46 \mathrm{FTE}$, and the mean number of staff in new universities decreased from 2.4 to 2.37 FTE.

Respondents were asked for the FTE number of staff in professional, clerical and other posts.

\subsection{Professional posts}

Of the 78 institutions which had staff with the care and servicing of the law collections as their sole or principal function, only 2 ( 1 old university and 1 "other" institution) did not have a professional post (2013: 2). Overall, then, of the 78 responding law libraries with staff who met the definition, $97.4 \%$ had a designated professional who could dedicate a significant proportion of their time to the needs of the law service (2013: $97.6 \%$ ). The number of professional FTE posts ranged from 0.10 to 12.10 (2013: 0.25 to 10.9 ) and $50 \%$ of institutions (2013: 48\%; 2012: 57\%) with any professional posts had exactly $1.0 \mathrm{FTE}$.

In old universities, 15 of the 36 respondents had exactly 1.0 professional FTE, with 12 institutions with less than 1.0 professional FTE (13 in 2013); 9 had more than 1.0 professional FTE (9 in 2013) and the maximum was 7.5 professional FTE posts (7.4 in 2013). The mean for old universities was 1.35 professional FTEs (2013: 1.37 FTEs). The results show a very slight decrease in the level of professional staffing in old universities. 
In new universities, 22 of the 39 respondents had exactly 1.0 FTE professional post, with 13 institutions with less than 1.0 FTE (14 in 2013); 4 had more than 1.0 FTE (7 in 2013) and the maximum was 12.10 FTE professional posts. The mean for new universities was 1.35 (2013: 1.35 FTE). These results indicate no real change in the level of professional staffing at new universities. In the 3 "other" institutions, one had 0 FTE, one had 1.0 FTE and one had 4.0 FTE (2013: 1 at 1.0 FTE, 1 at 4.0 FTE).

\subsection{Clerical posts}

Turning to clerical posts, 33 institutions out of 78 respondents had clerical staff who met the definition given in section 17 . Of the 45 who had library staff but no clerical staff, 15 were old universities, 28 were new universities and 2 were "other" institutions.

For the 33 institutions that did have clerical staffing, numbers ranged from 0.1 to 16.1 (2013: 0.20 to 18.1 ), with median of 1.0 (2013: 1.0) and a mean of 3.4 (2013: 2.9). Fifty eight percent of old universities reported clerical staff for law as opposed to $28 \%$ of new universities (2013: $58 \%, 34 \%)$.

As found in past years, old universities typically had larger numbers of clerical staff. Eight of the 21 old universities with clerical staff had four or more such staff and the mean was 3.5 (2013: 3.1), whereas of the 11 new universities with clerical staff only 1 (2013:2) had four or more such staff.

A partial explanation for the large difference between the presence of clerical staffing in old and new universities could be drawn from the location of the law library. Of the 16 (2013: 14) institutions with more than 2 FTE clerical staff, 9 or $53 \%$ had a law library located separately from other collections (2013: 7 or 50\%). Of these 9 institutions, 8 (89\%) were old universities. Where there is a separate law library, staffing is less likely to be shared between subjects, and circulation and other activities will be dedicated to the law collections. It is noteworthy however, that $42 \%$ of respondents who had a single law library in a separate location had professional staff but no clerical staffing or "other" staff dedicated to the law service (2013: $44 \%)$.

\subsection{Staff employed in other posts}

Seven institutions (2013: 7) noted law library staff, other than clerical or professional staff, who met the criterion noted in section 17 above. Of these, 5 were old universities and 2 were new universities. FTE numbers of such staff ranged from 0.21 to 1.0 again (2013: 0.21 to 1.0). Their duties were specified by four of the seven respondents and included "IT support", "building attendant (extended hours)", "Assistant Manager" and "Assistant Faculty Librarian".

\subsection{Qualifications of staff}

Respondents were asked to indicate how many of the staff whose principal function was the care of the law collections had a professional librarianship or information science (LIS) qualification or an academic or professional qualification in law.

Seventy eight respondents or $86 \%$ (2013: 84 or $90 \%$ ) of respondents had at least one member of staff who had a LIS qualification, although for 20 institutions this was less than one full-time member of staff (2013: 21).

Forty one (2013: 42) institutions had exactly one FTE member of staff with a LIS qualification and 8 (2013: 9) had three or more FTE staff with such a qualification.

Importantly it is still true to say that there was no unqualified staff in professional posts. 
Twenty two of the 78 respondents representing $28.2 \%$ of institutions (2013: $21.5 \%$ ) had staff with an academic or professional qualification in law. This is a significant increase in the level seen in most years. Seventeen (2013: 15) had at least one member of staff so qualified, and 13 (2013: 12) had exactly 1.0 FTE staff member with a law qualification.

As found in past surveys, library staff with law qualifications were much more common in old universities. Looking at only those institutions which had any staff which met the criterion noted in section 17 above, in old universities 39\% (2013: 35\%) of law libraries had law qualified staff, compared to new universities where only 21\% (2013: 16\%) had law qualified staff. None (2013: 0) of the "other" institutions had such staff. Overall, $64 \%$ of the libraries with law qualified staff were in old universities, one percent lower than last year.

\section{The SLS Statement of Standards, 2009}

Two questions were added in 2010 at the request of SLS to gauge how far law librarians were aware of the 2009 Society of Legal Scholars Statement of standards for university law library provision in the United Kingdom and whether they had had occasion to use it in discussions on funding and administration of the law collection in their institution. It is pleasing to record that 76 or $84 \%$ of respondents (2012: 80 or $87 \%$ ) were still aware of the revised Statement and as many as 55 or $60 \%$ (2012: 55 or $60 \%$ ) had used the Statement in discussions.

\section{The future}

Since 2004 and every other year since, we asked for the personal views of respondents on the changes they envisage over the next five years to the provision of legal information within their library. We repeated the questions this year.

\subsection{Electronic v Paper}

Ninety (99\%) of respondents (2012: 92 or $100 \%$ ) gave their views on the balance of provision between electronic and paper access to legal information. 54\% (2012: 65\%) felt the move would be significantly in favour of electronic access. However, 39\% (2012: $28 \%$ ) considered that in the next five years in their library the balance would move only marginally in favour of electronic access. Just 7\% (2012: 7\%) felt the balance would remain constant. As in all previous surveys no respondents considered there would be a move away from electronic access.

Over the last six years respondents' views on the future have moved away from considering only a marginal move towards electronic provision possible, towards a consistent majority considering a significant move towards electronic provision likely.

Looking at the differences between types of institution, $43 \%$ (2012: $31 \%)$ of old universities felt the move towards electronic would be marginal, whilst $33 \%$ (2012: $22 \%$ ) of new universities also thought the move would be marginal. There was agreement in the proportion of old and new universities who thought the move towards electronic would be significant: $50 \%$ of old university respondents (2012: $61 \%$ ) and $60 \%$ of new university respondents (2012: 73\%) respectively.

Since 2004, when these questions were first posed, the views of the sectors have become more closely aligned, and now a high percentage of respondents in all sectors consider library provision will move significantly in favour of electronic delivery.

\subsection{Monographs v Serials}

Eighty seven (96\%) of respondents provided their views on the balance of expenditure between monographs and serials. The results consolidate trends established in past years. At $56 \%$, most respondents considered the balance would remain constant (2012: $48 \%$ ). $22 \%$ of 
respondents considered that the balance would move marginally in favour of serials (2012: $20 \%$ ) and $15 \%$ of respondents considered that the balance would move marginally in favour of monographs (2012: $20 \%$ ). $7 \%$ of respondents thought the balance would move significantly in favour of serials (2012: $10 \%)$ and no respondents thought the balance would move significantly in favour of monographs (2012: $2 \%)$.

There was majority agreement between respondents from old and new universities that the balance would remain constant.

\subsection{GB materials and EU materials v Foreign and International materials}

Finally, 89 (98\%) respondents provided their views on the changes over the next five years in the proportion spent in their library purchasing legal materials relating to the law of Great Britain and the European Union as compared with foreign and international law. The pattern is very similar to that reported in the past three surveys.

At $67 \%$, most respondents considered the proportion would remain constant (2012: $74 \%$ ). $20 \%$ of respondents considered that the proportion would move marginally in favour of foreign and international (2012: $11 \%$ ) and $7 \%$ thought the proportion would move marginally in favour of Great Britain and the EU (2012: $12 \%)$. Only 5\% of respondents thought the proportion would move significantly in favour of Great Britain and the EU (2012: $2 \%$ ) and only $1 \%$ of respondents thought the proportion would move significantly in favour of foreign and international (2012: 1\%).

When analysed by type of institution there was considerable unanimity of response between old and new universities. Similar majority numbers (old $64 \%$ and new $74 \%$ ) believed that the proportion would remain constant, whilst the next highest percentages for both old (23\%) and new $(17 \%)$ universities were for the proportion moving marginally in favour of foreign and international law.

Overall, there was considerable uniformity in responses between old and new universities on future trends across the higher education sector.

\section{Acknowledgements}

Firstly I must thank Dr Peter Clinch whose original survey template is the basis of this report. Secondly my job has been made considerably easier by having Laura Griffiths, an Assistant Librarian at IALS, to fill the important administrative and statistical roles with her usual accuracy and efficiency. She continues to contribute significantly to the administration of the survey and has helped me by calculating many of the statistics for the report.

\section{References}

Gee, David (2014) SLS/BIALL Academic Law Survey 2012/2013. Legal Information Management. 14(3), 215-233.

Gee, David (2013) SLS/BIALL Academic Law Survey 2011/2012. Legal Information Management. 13(4), 260-277.

Gee, David (2012) SLS/BIALL Academic Law Survey 2010/2011. Legal Information Management. 12(3), 218-232.

Clinch, Peter (2011) SLS/BIALL Academic Law Library Survey 2009/2010. Legal Information Management 11(4), 272-288. 
Clinch, Peter (2010) SLS/BIALL Academic Law Library Survey 2008/2009. Legal Information Management 10(4), 291-305.

Clinch, Peter (2009) SLS/BIALL Academic Law Library Survey 2007/2008. Legal Information Management 9(3), 205-220.

Society of Legal Scholars (2009) A library for the modern law school. A statement of standards for university law library provision in the United Kingdom - 2009 revision. Available at URL: http://www.legalscholars.ac.uk/documents/SLS-Library-for-a-Modern-Law-SchoolStatement-2009.pdf

\title{
Appendix
}

\section{List of the 91 academic law libraries in the UK and Ireland that returned a completed} 2013/2014 survey questionnaire

\author{
Aberdeen University \\ Abertay University \\ Aberystwyth University \\ Aston University \\ Bangor University \\ Bedfordshire University \\ Birkbeck, University of London \\ Birmingham City University \\ Birmingham University \\ Bodleian Law Library (Oxford University) \\ Bolton University \\ Bournemouth University \\ BPP University \\ Bradford College \\ Brighton University \\ Bristol University \\ Brunel University \\ Buckingham University \\ Canterbury Christ Church University \\ Cardiff University \\ Central Lancashire University \\ Chester University \\ City University \\ Coventry University \\ Cumbria University \\ Derby University
}


Dublin Business School

Dundee University

Durham University

Edge Hill University

Essex University

Exeter University

Gloucestershire University

Greenwich University

Heart of Worcestershire College

Hertfordshire University

Hull University

IALS (Institute of Advanced Legal Studies)

KCL (Kings College London)

Keele University

Kent University

Kingston University

Lancaster University

Leeds Beckett University

Leicester University

Lincoln University

Liverpool John Moores University

London Metropolitan University

Manchester Metropolitan University

Middlesex University

Newcastle University

Northumbria University

Nottingham Trent University

Nottingham University

Oxford Brookes University

Plymouth University

Portsmouth University

Queen Mary and Westfield College

Queen's University Belfast

Reading University

Robert Gordon University 


\author{
Salford University \\ School of Oriental and African Studies \\ Sheffield Hallam University \\ Sheffield University \\ South Wales University \\ Southampton Solent University \\ Southampton University \\ Squire Law Library (Cambridge University) \\ St Mary's University College \\ Staffordshire University \\ Stirling University \\ Strathclyde University \\ Sunderland University \\ Surrey University \\ Sussex University \\ Swansea University \\ Teesside University \\ Trinity College Dublin \\ UCC (University College Cork) \\ UCL (University College London) \\ UEA (University of East Anglia) \\ UEL (University of East London) \\ Ulster University \\ University of Law \\ University of Leeds \\ University of Winchester \\ UWE (University of the West of England) \\ Warwick University \\ Westminster University \\ York University
}

